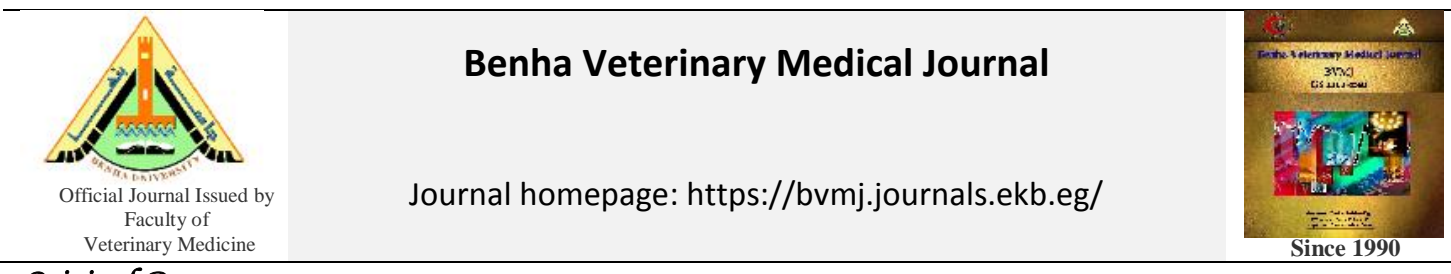

Original Paper

\title{
Prevalence of some food poisoning bacteria in semi cooked chicken meat products at Qaliubiya governorate by recent Vitek 2 compact and PCR techniques
}

Sobhy, Asmaa and Shaltout, Fahim

Department of Food Hygiene and Control, Faculty of Veterinary Medicine, Benha University,, Egypt

\section{ARTICLE INFO}

\section{Keywords}

E.coli

PCR.

Staph. aureus

Vitek 2

Received 09/03/2020

Accepted 22/04/2020

Available On-Line

08/09/2020

\begin{abstract}
Bacterial foodborne pathogens are important food safety issue worldwide. Rapid and accurate identification of bacteriological pathogen isolated from food staff is important both for food quality assurance and for the tracing of outbreaks of bacterial pathogen. A total of ninety random samples of semi cooked chicken meat products represented by strips; pane and nuggets (30 of each) were collected from different supermarkets at Qaliubiya governorate for bacteriological examination using conventional culture method and rapid modern techniques as Vitek 2 compact system and molecular identification by PCR technique. The obtained results revealed that Staph. aureus and E.coli incidence were 20\% and $10 \%$ in strips, $26.6 \%$ and $13.3 \%$ in chicken pane and $26.6 \%$ and $23.3 \%$ in nuggets for total examined samples. Also, E.coli was serologically typed as O127, O128, O153, O157 and O91. Staph. aureus and E. coli were identified in all examined samples by confirmatory identification using Vitek 2 compact system in examined 10 random samples of the chicken products. Results recorded accuracy $100 \%$ for examined samples and showed that the Vitek 2 system is a suitable tool for rapid and direct identification of gram-positive cocci and gram-negative bacilli from chicken products. The PCR technique revealed that there were one or more virulence genes in E. coli (stx1\&stx2) strains isolated from the examined samples of chicken products.
\end{abstract}

\section{INTRODUCTION}

Food processing is an important industry worldwide. One of the major problems threatening food industry is the contamination with foodborne microbes of human origin resulting from improper handling and processing. Microbial contamination reduces shelf life and food quality leading to food infection and poisoning outbreaks, some of which are life threatening. Continuous monitoring of food processing is essential to avoid potential health problems (Al-Bahry et al., 2014).

The coagulase positive Staphylococci, which include Staph. aureus, the most pathogenic species, that is considered the third important cause of food borne diseases in the world. This pathogen is considered an excellent indicator of thermal processing inefficiency, inadequate hygienic conditions during food production, preparation or inadequate cooling (Melheiros et al., 2010).

Enteropathogenic E.coli organisms constitute public health hazards as they may give rise to sever diarrhea in young children and adolescents as well as food poisoning and gastroenteritis among adult consumer (Bohaychuck et al., 2006). So, with the constant increase in semi cooked chicken meat products consumption worldwide and the variety of products and consumer demand.

Bacteriological criteria as are very important; they provide guidance in what concerns the acceptability of food and manufacturing processes, manipulation and distribution.
The automated microbial identification system have become widely used in both clinical and food microbial laboratories .These systems offer some advantages over conventional methods including reduce labor ,reduce human error, increased samples throughput and rapid test result .Some example of automated microbial identification is Vitek systems and PCR technique (Darbandi, 2010).

\section{MATERIAL AND METHODS}

2.1. Collection of samples: Ninety of semi cooked chicken products of pane, strips and nuggets (30 of each) were collected from different supermarkets at Qaluobia governorate. Samples were transported directly and aseptically to the laboratory in an ice box.

2.2. Preparation of samples (APHA,2001): under aseptic condition twenty five grams of each sample were weighted and transferred into a sterile homogenizer flask containing $225 \mathrm{ml}$ of $0.1 \%$ sterile buffered peptone water then homogenized at $2000 \mathrm{rpm}$ for $1-2 \mathrm{~min}$. to provide a homogenate of $1 / 10$ dilution, one $\mathrm{ml}$ from the original dilution was transferred to another sterile tube containing 9 $\mathrm{ml}$ of $0.1 \%$ sterile buffered peptone water and mixed well to make the next dilution, from which further decimal serial dilutions were prepared. The prepared dilutions were subjected to the following examinations

2.3. Isolation and identification of staph. aureus: It was

\footnotetext{
* Corresponding author: Shaltout, Fahim, Department of Food Hygiene and Control, Faculty of Veterinary Medicine, Benha
} University,, Egypt 
carried out according to ICMSF, 1996

2.4. Isolation and identification of E.coli: It was carried out according to ISO, 2007.

2.5. Confirmatory biochemical identification of Staph. aureus and E.coli isolates by Vitek 2 compact system technique: It was carried out according to pincus (2006).

2.6. Molecular identification of coagulase gene of Staph. aureus and Shiga toxins virulence genes of E.coli: PCR technique was performed to 10 random samples of recorded results of traditional methods. Firstly, DNA extraction (Shah et al., 2009) then amplification of E.coli (Fagen et al., 1999) and amplification of Staph. aureus (Mehrorta et al., 2000) was adopted.

\section{RESULTS}

As shown in table 1 results revealed that, a total of 22 isolates of coagulase positive Staph. aureus were isolated from examined samples those were $6(22 \%)$ from strips, 8 (26.6\%) from pane and $8(26.6 \%)$ from nuggets. Moreover, the incidences of E.coli were $10 \%, 13.3 \%$ and $23.3 \%$ of examined chicken samples of strips, pane and nuggets respectively.

Table 1 Prevalence of some food-borne pathogens in examined chicken products samples $(\mathrm{n}=30)$

\begin{tabular}{|c|c|c|c|c|c|c|}
\hline \multirow[t]{3}{*}{ microorganism } & \multicolumn{6}{|c|}{ Examined chicken samples $(\mathrm{n}=30)$} \\
\hline & \multicolumn{2}{|c|}{ Chicken strips } & \multicolumn{2}{|c|}{ Chicken pane } & \multicolumn{2}{|c|}{ Chicken nuggets } \\
\hline & No. & $\%$ & No. & $\%$ & No. & $\%$ \\
\hline Staph. aureus & 6 & 20 & 8 & 26.6 & 8 & 26.6 \\
\hline E. coli & 3 & 10 & 4 & 13.3 & 7 & 23.3 \\
\hline
\end{tabular}

Table 2 showed that the prevalence of serologically identified E.coli in strips samples were Enterotoxigenic E.coli O127: H6 (66.6\%) and Enteropathogenic E.coli
O128: $H 2(33.33 \%)$, identified $E$. coli in pane were Enterotoxigenic E.coli O127: H6 (50\%) and Enterohemorrhagic E.coli O157:H7 (25\%) and Enteropathogenic E.coli O153:H2 (25\%) but the prevalence in nuggets samples were Enterohaemorrhagic E.coli O157:H7 (28.5\%), Enterotoxigenic E.coli O127:H6 (57.1\%) and Enteropathogenic E.coli O91:H21 (14.2\%).

Table 2 Serotyping of E.coli isolated in examined chicken products samples. E.coli serotypes $\quad$ Examined chicken samples $(\mathrm{n}=30)$

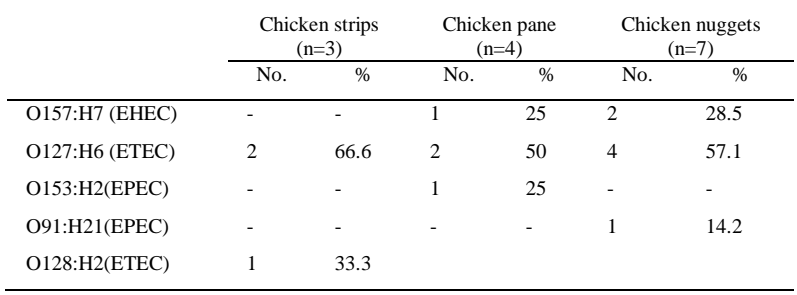

Table 3 and 4 showed confirmatory identification of 10 traditionally isolated Staph. aureus and E.coli (5 for each species) from examined products by Vitek 2 compact system. The results were identically recorded by conventional method. As, it reported that using of Vitek 2 compact system provides very good and trustable accuracy and reproducible results as shown in reported samples that mean $100 \%$ when compared with conventional method. Also, coagulase positive Staph. aureus in 5 random isolated Staph. aureus and virulence genes of E.coli (stx1 \&stx2) were reexamined by using one of the most recent developments PCR techniques.

Table 3 Identification of Staph. aureus by using recent biochemical technique(Vitek 2 compact system).

\begin{tabular}{|c|c|c|c|c|c|c|c|c|c|c|c|c|c|c|c|c|c|}
\hline \multirow[b]{2}{*}{2} & \multicolumn{17}{|c|}{ Biochemical Details } \\
\hline & AMY & + & 4 & PIPLC & - & 5 & $\mathrm{dXYL}$ & - & 8 & ADH1 & + & 9 & BGAL & + & 11 & AGLU & + \\
\hline 13 & APPA & - & 14 & CDEX & - & 15 & AspA & - & 16 & BGAR & - & 17 & AMAN & - & 19 & PHOS & - \\
\hline 20 & LeUA & + & 23 & ProA & - & 24 & BGURr & - & 25 & AGAL & - & 26 & pyrA & - & 27 & BGUR & - \\
\hline 28 & AlaA & - & 29 & TYrA & - & 30 & dSOR & - & 31 & URE & - & 32 & POLYB & + & 37 & dGAL & - \\
\hline 38 & dRIB & + & 39 & iLATk & + & 42 & LAC & - & 44 & NAG & + & 45 & dMAL & - & 46 & BACI & + \\
\hline 47 & NOVO & - & 50 & NC6.5 & + & 52 & dMAN & + & 53 & $\mathrm{dMNE}$ & + & 54 & MBdG & + & 56 & PUL & - \\
\hline 57 & $\mathrm{dRAF}$ & - & 58 & O129R & + & 59 & SAL & + & 60 & SAC & + & 62 & dTRE & + & 63 & $\mathrm{ADH} 2 \mathrm{~s}$ & - \\
\hline 64 & OPT & ++ & & & & & & & & & & & & & & & \\
\hline
\end{tabular}

Table 4 Identification of E.coli by using recent biochemical technique (Vitek2 compact system).

\begin{tabular}{|c|c|c|c|c|c|c|c|c|c|c|c|c|c|c|c|c|c|}
\hline & & & & & & & & Biochemical & $1 \mathrm{De}$ & & & & & & & & \\
\hline 2 & APPA & - & 4 & $\mathrm{ADO}$ & - & 5 & LeuA & + & 7 & IARL & + & 10 & ERYa & - & 12 & BGAL & - \\
\hline 10 & BGAL & - & 14 & BANG & - & 15 & $\mathrm{ARBa}$ & - & 18 & AMYa & - & 19 & dGALa & + & 20 & GENa & - \\
\hline 17 & APPA & + & 23 & LACa & - & 24 & MAdGa & + & 26 & dCELa & - & 27 & GGT & - & 28 & dMALa & + \\
\hline 25 & ELLM & - & 30 & NAGA1 & + & 32 & dMNEa & + & 33 & dMELa & - & 34 & dMLZa & - & 38 & ISBEa & - \\
\hline 32 & IRHAa & - & 40 & XLTa & - & 42 & dSORa & + & 44 & SACa & + & 45 & URE & + & 46 & AGLU & $(+)$ \\
\hline 43 & dTURa & + & 48 & dTREa & - & 49 & $\mathrm{NO} 3 \mathrm{a}$ & - & 51 & IARAa & - & 54 & DGATa & - & 53 & ESC & - \\
\hline 50 & IGLTa & + & 55 & dXYLa & - & 56 & LATa & + & 58 & ACEa & + & 59 & CITa & + & 60 & GRTas & $(-)$ \\
\hline 61 & IPROa & + & 62 & $2 \mathrm{kGa}$ & & 63 & NAGa & + & 64 & dGNTa & + & & & & & & \\
\hline
\end{tabular}

Fig. 1 showed that from 5 samples were confirmed for presence of coagulase gene in examined chicken products in 2 pane, 2 nuggets and one strip there were $4(80 \%)$ coagulase positive Staph. aureus.
Fig. 2 indicated that agarose gel electrophoresis of multiplex PCR for detection of stx1 (614 bp) and stx2 (779 bp) virulence genes for characterization of Enteropathogenic E.coli. The results of molecular 
identification showed the presence of 2 virulence genes in the chicken products in all E.coli isolates.

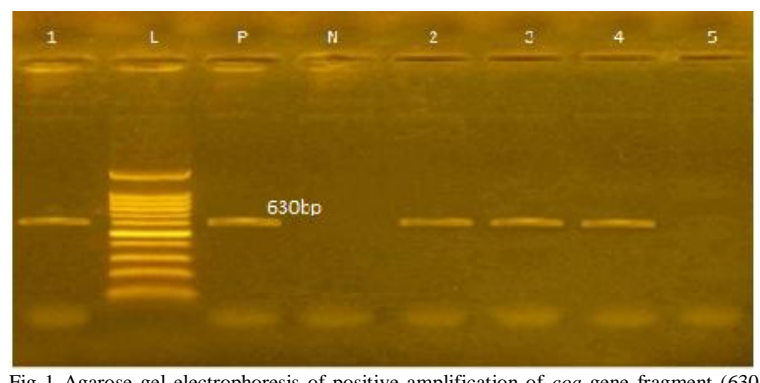

Fig 1 Agarose gel electrophoresis of positive amplification of coa gene fragment (630 bp)of S.aureus isolates. P: control positive, N: control negative, L : DNA ladder, Lane1, 2, 3\&4: positive coa gene fragment (630 bp), Lane 5: negative coa gene fragment

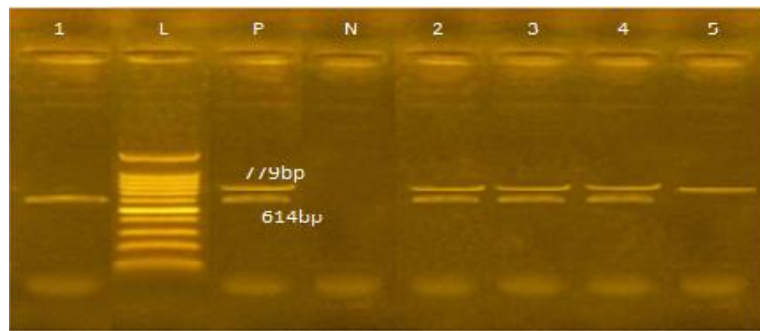

Fig 2 Agarose gel electrophoresis showing results of multiplex PCR for detection of (stxl and stx2) genes for characterization of Enteropathogenic E.coli. Lane L: DNA ladder. Lane P: control positive .Lane N: control negative. Lane1(E.coli O128): Positive strain for stx1( 614 bp). Lane2(E.coli O157), 3 (E.coli O127)and 4(E.coli O91): Positive strain for stxl( $614 \mathrm{bp}$ ). Lane2(E.coli O157), 3 (E.coli O127)and 4(E.coli O91): Positive (779bp).

\section{DISCUSSION}

The current study was designed to isolate and identify Staph. aureus and E.coli from some semi cooked chicken meat products in Qaluobia governorate using conventional methods, automated biochemical method and molecular technique for identification of coagulase gene of Staph. aureus and virulence genes of E.coli.

Table [1] revealed that the occurrence of Staph. aureus was $22(24.5 \%)$ of samples represented by $8(26.6 \%)$ samples from pane, $8(26.6 \%)$ samples for nuggets and 6 samples $(22 \%)$ for strips .Moreover 68 out of 90 ones were accepted, as they were free from coagulase positive Staph. aureus isolates according to EOS (2005) by conventional culture method.

As collected samples were frozen or chilled raw products, the high incidence of Staph. aureus in chicken products especially in pane and nuggets could be attributed to that local manufacturers use of untreated and contaminated additives and spices and/or miss handling of these products.

These results came in accordance with those obtained by Atia (2017), El-Kholy (2018), and Arab (2010). furthermore, higher incidence reported by Abou-ElRoos (2010) include $44 \%$ in pane and $40 \%$ in nuggets; Amin (2015) reported $40 \%$ in nuggets and Shaltout et al.(2018) observed $56.6 \%$ in pane, $40 \%$ of nuggets and $43.3 \%$ in strips .While, lower incidence recorded by Shaltout et al., (2002) was 6\% and Olimpia (2006) detected $15 \%$ in nuggets and Edris (2015) recorded 10\% in nuggets. Otherwise, Shanab (2014) failed to detect Staph. aureus in examined samples. The presence of Staph. aureus in heat treated chicken products may be due to its contamination from food handlers inadequate cleaned equipment or post processing contamination (Duffy et al.,2000).
Also, table [1] showed that nuggets samples were contaminated by E.coli rather than other chicken products, the results is nearly similar to that obtained by Samaha et al.,(2012) where $12 \%$ in pane; by Edris (2015) where $25 \%$ in nuggets; and Elkohly (2018) where $16.6 \%$ of nuggets. Although lower results were recorded by Lee (2009) include 4.6\%; while Arab (2010) reported 6.67\% in pane and Khallaf (2019) observed $6.67 \%$ in pane but AbdElSattar et al., (2016) recorded $36 \%$ in pane; Shaltout et al.(2018) detected $46.6 \%$ in pane, $30 \%$ in nuggets and $43 \%$ in strips as higher results. Although, Younes (2014) failed to isolate this microbe from pane and nuggets

Table [2] showed that the identified E.coli serotypes that is nearly similar to obtained by Karadal (2013) O157; Awadallah (2014) O128; Emara (2016) O128, O91; Atia (2017) O91, O127,O153 and O128; Elkholy (2018) $O 91, O 153$ and $O 128$. The variation in the results between different authors may be due to the differences in manufacture practices, handling from producers to consumers and the effectiveness of hygienic measures applied during production. The presence of $E$. coli in food is considered as an indicator of faults during preparation, handling, storage or service. So, there are 3 main routes by which microorganisms enter the food through raw food used, food handlers and the surrounding environment. Fecal contamination can act as cross contamination of raw food which is never sterile and careful working practices are essential source of E. coli infection (ICMSF, 1996).

Table [3 and 4] showed identification of gram positive Staphy. aureus and gram-negative E.coli of 10 traditionally isolated isolates by using Viteck2 compact system from examined chicken product samples. The correlations between the two methods were $100 \%$. Nearly similar results were recorded by (Mellissa et al., 2017) and (Spanu et al., 2003) was identified Staph. aureus with accuracy rate $99.6 \%$ when compared by PCR technique. But, Khalaf (2019) were identified isolated Staph. aureus and E. coli in a percentage $50 \%$ and $6.6 \%$ from chicken pane. This study showed that the PCR technique was very convenient to take DNA templates directly from the chicken meat products samples after DNA extraction and there is no need to take from the culture as it time-consuming, labor intensive and very costly as reported by Chen et al., (2012) and Kim et al., (2014) who examined directly from food samples without the use of bacterial cultures but with different primers used in this study unlike Latha et al., (2014) who examined their PCR technique by the use of bacterial culture.

Five random Staph. aureus samples; 3 positive and 2 negative reexamined by PCR, there was great agreement between results of conventional method and PCR technique in four random samples; four positive and 1 negative while one sample was negative by conventional method for Staph. aureus, showed positive results with PCR (false negative) as in fig [1]. This result clarified the high sensitivity of the PCR technique in detection the false negative results of the traditional microbiological culture method. Similar results were obtained by Chen et al., (2012) and Moustafa (2016) who detected a false negative result negative by conventional method and positive by $\mathrm{m}$ PCR. The false negative result may due to the low number of bacterial load which can't be detected by microbiological assay. So, the m PCR assay has the potential to be used in routine diagnostic laboratories and also as a rapid screening tool in food testing laboratories to identify food samples quickly especially in case of outbreaks. 
Fig [2] revealed that there were one or more virulence genes in E.coli strains isolated from the examined samples of chicken products.E.coliO127:H6,O157:H7\&O91:H21 have the 2 virulence genes Stx1and Stx2), WhileO128:H2 have Stx1 virulence gene and O153:H2 have Stx2 virulence gene of Escherichia coli. Similar results were recorded by Emara (2016), Atia (2017) and Younes (2017) who recorded the different virulence genes in some heattreated chicken meat products. E.coli strains possess that genes were more toxigenic and hazardous to consumer health.

The presence of Shiga toxins E.coli in all examined samples by PCR technique revealed that there were improper hygienic faults during preparation, distribution and storage. Shiga toxin genes are found in more than 200 serotypes of different strains of E.coli strains, of which $\mathrm{O} 157$ and non $\mathrm{O} 157$ serotypes are quite well known for their disease-causing ability (Page and Liles, 2013).

\section{CONCULSION}

Finally, the current study allows concluding that the possibility of contamination of semi cooked chicken meat products with such serious pathogens remains as a public health problem. Thus, all precautions of proper sanitation during manufacture, handling and storage of such chicken products should be adopted to control these serious pathogens and to obtain a maximum limit of safety to consumers.Vitek 2 compact system and PCR technique showed more effective and rapid method for identification of food borne pathogen.

\section{REFERENCES}

1. Abd-El Satter, A, M.; Hassanien, F, M. and Nada, S. M. 2016: Incidence and importance of some pathogenic microorganisms contaminating meat products. M. V. Sc., Thesis (Meat hygiene), Fac. Vet. Med., Benha University.

2. Abou-El-Roose, N, A. and Atwa-Elham, I. 2010 Bacteriological status of some Egyptian chicken products.Zag.Vet.J.,38(4):133-134.

3. Al-Bahry, S.N.; Mahmoud, I.Y.; Al-Musharafi, S. K. and Sivakumar, N. 2014: Staph. aureus contamination during food preparation, processing and handling. Int. J. Chemical Engineering and Applications, 5(5): 388-392.

4. American public Health Association APHA 2001: compendium of methods for the microbiological examination of food $4{ }^{\text {th }} \mathrm{Ed}$. Aquafind.com/articles/Value Added -fishprocess.php

5. Amin, A, A. 2015: Staphylococcaus aureus enterotoxins in some breaded /half cooked chicken and fish products. M. V. Sc. (Meat Hygiene). Fac. Vet. Med., Benha University

6. Arab, W. 2010: Quality improvement of meat meal in University restaurant.Ph.D.V.SC., Thesis (Meat Hygiene),Fac. Vet. Med. Benha University.

7. Atia, A. A. 2017: E.coli and Staph. aureus in some meat and poultry products. Ph. D. V. Sc., Thesis, Fac. Vet. Med., Benha University.

8. Awadallah, M. A., Ahmed, H. A. and Merwad, A. M. 2014: Prevalence of Non O157 Shiga toxin producing E. coli and enterotoxigenic staphylococcus in ready to eat meat products ,handlers and consumer in Cairo, Egypt. Global Vetreneria 12(5):592-699.

9. Bohaychuk, V.; Gensler, G; King,R.; Mannien,K.; Sorensen, O. and Stiles, M.2006:Occurance of pathogens in raw and ready to eat meat and poultry products collected from the retail markets place in Edmonton, Albetra, Canada. J. Food protects 96(9):2176-2182.

10. Chen, J., Tang, J., Liu, J., Cai, Z., Bai, X., 2012. Development and evaluation of a multiplex PCR for simultaneous detection of five foodborne pathogens. Journal of Applied Microbiology.112: 823-830.

11. Darbandi ,F.2010: Parrallel comparison of accuracy in vitek 2 automated analyzer and API20E/API20NE microsystems. University college of Boras,school of engineering,SE50190BORAS.

12. Duffy, G., Kilbride, B., Sheridan, J.J., Blair, I. S., McDowell, D. A. 2000: A membrane immunofluorescent viability staining technique for the detection of Salmonella spp. from fresh and processed meat samples. J. Appl. Food Microbiol., 89(4):587-594

13. Edris-Shimaa,N.2015: Microbial and chemical investigation of some heat-treated chicken meat products with special reference to recent techniques. Ph. D. V. Sc., Thesis, (Meat Hygiene), Fac. Vet. Med., Benha University

14. Egyptian Organization for Standardization (EOS) 2005 products of meat poultry treated with heat .No.3493/2005.

15. El-Kholy, R.R.A.2018: Effect of some preservatives on the bacteriological quality of some chicken meat products. $\mathrm{Ph} . \mathrm{D}$. V. S.c, Benha University.

16. Emara, N. M.A. 2016: Trancability diahrreagenic E.coli in meat products with special reference to enterohaemorrhagic strains . Ph. D. V. Sc., Thesis, (Meat Hygiene), Fac. Vet. Med., Benha University

17. Fagan, P.; Honitzky, M.; Bettelheim, K. and Djordjecvic, S.1999: Detection of Shiga like toxin (stx1 and stx2), Intimin (eaeA) and Enterohemorrhagic E.Coli (EHEC) Hemolysin (EHEC hlyA) genes animal. feces by multiplex PCR. APPL. Environ. Microbiol., 65 (2):868-872.

18. International Comission on Microbiological Spesificans for foods "ICMSF"1996: Salmonella In. Roberts, T.A., Baired parker, A.C., and Tompkin, R.B. eds. Microorganisms in foods 5:Microbiological specifications of food pathogens. $1^{\text {st }}$ Ed, Blackie Acadimic \&Professional, London, UK, pp 217 264.

19. International Specifications Organization "ISO" 2007: Microbiology of Food and Animal Feeding StuffsGuidelines on Preparation and Production of Culture MediaPart 2: Practical Guidelines on Performance Testing of Culture Media. ISO, Geneva.

20. Karadal, F.; Ertas, N.; Hizlisoy, H.; Abay,S. and Serhat,A.2013: Prevalence of E. coliO157:H7 and their verotoxins and Salmonella spp. In processed poultry products. Journal of food safety 33(3):313-318.

21. Khallaf-Fatma,H.2019:Evaluation of hygienic status of meat meals in some food catering establishments .M. V. Sc. Thesis, (Meat Hygiene Dep.), Fac. Vet .Med., Benha University.

22. Kim, J., Rhim, S., Kim, K., Paik, H., Lee, J. 2014. Simultaneous Detection of Listeria monocytogenes, Escherichia coli O157:H7, Bacillus cereus, Salmonella spp., and Staphylococcus aureus in Low fatted Milk by Multiplex PCR. Korean J. Food Science, 34(5): 715-716.

23. Latha, C.C.A., Sunil, B.V.A., Jolly, D. 2014. Multiplex PCR assay for the simultaneous detection of four common food pathogens in meat. Journal of Foodborne and Zoonotic Diseases 2(3): 45-49.

24. Lee,G.Y., Jange, H.I., Hawang ,I.G. and Rhee, M.S. 2009: Prevalence and characterization of pathogenic E.coli isolated from fresh beef, poultry and pork in Korea. Inter J. Food Microbiol., 134:196-200.

25. Malheiros, P. S., Passos, C. T., Casorin, L. S., Serraglia, 1 and Tondo, E.C.2010: Evaluation of growth and transfere of $S$. aureus from poultry meat to surfaces of stainless steel and polyethylene and their disinfection of control, 21:298301.

26. Mehrotra, M.; Wang, G. and Johnson, W. M. 2000: Multiplex PCR for detection of genes for $S$. aureus enterotoxins. exfoliative toxins, toxic shock syndrome toxine1, and methicilline resistance .J. Clin. Microbiol., 38(3):1032-1035

27. Mellissa-

Duran,H.;Jacome,E.L.;Castro,C.G.;Pena,O.S.;Rodriguez,A.J; Cedejas ,F.R2017:Comparison of the Miroscan walkaway and vitek 2 compact system for the identification and 
susability of clinical gram positive and gram negative bacteria . Dajjasal, Pekarek PM, Mills T .J, Nearwj , Sallbrook AGG,Hejna J.

28. Moustafa,N. Y., Abd El-Hafiz, Reham, M. and ElBahy,Engy F.2016: Incidence of Staphylococcus aureus and Salmonella in poultry meat. Global Vetrineria,16(6):570-578.

29. Olimpia,P.;Giuseppe,B.;Marlena,A.;Maria,A.andFrancesco, V.2006:Staphylococcus aureus and Staphylococcal enterotoxin A in breaded chicken products. J. Appl., Environ Microbiol., 72(11):7057-7062.

30. Page A.V. and Liles, W.C.2013: Enterohemorrhagic Escherichia coli Infections and the Hemolytic-Uremic Syndrome. Med. Clin. North. Am., 97(4): 681-695.

31. Pincus, D. 2006: Performance of the new vitek2NH card in a routine clinical laboratory, abstr c-010. Abstr. 10 $0^{\text {th }}$ Gen. Meet. Am. Soc. Microbiol. American. Society for Microbiology, Washington, DC.

32. Samaha, I.A, Ibrahim, H. A. A. and Hamada, M. O. 2012 Isolation of some retailed poultry meat in Alexandria province. Alex. J. Vet. Sc., 37(1):17-22.

33. Shah, D.; Shring, S., Besser, T. Call, D. 2009: Molecular detection of foodborne pathogens, Boca Raton: CRC Press, In Lui, D. (Ed). Taylor \& Francis group, Florida, USA, Pp.369-389.

34. Shaltout, F.A; El-Zahaby, D.I; Lotfy, L.M; and El-Shorah, H.F 2018: Bacteriological status of chicken meat products marketed at Menoufia governorate Benha Veterinary medical Journal, 34 (1): 28-40

35. Shaltout, F.A. 2002: Microbiological aspect of semi cooked chicken products. Benha University , Vet. Sc., Med. J (2):17-19.

36. Shanab, M. S. M. 2014: Quality of some locally manufactured chicken products. M. V SC. Thesis ,Fac. Vet. Med. Meat Hygiene, Benha University.

37. Sharaf-Doaa,M.R.2019:Bacteriological and molecular studies on some gram negative bacteria isolated from edible egg and poultry products. D.V. Sc. Thesis, (Microbiology Dep.), Fac. Vet. Med., Benha University.

38. Spanue,T.T.; Sanguinetti, M and Faddi,G 2003:use of the viteck 2 system for rapid identification of clinical isolatesof Staphylococci aureus from blood stream infection.J.clin.,Microbiol.2003.Sep.41(9):4259-4263

39. Yones,A.F.O.2014: Enterobacteriacea in chicken meat products .M. V. Sc. Meat Hygiene. Faculty of Veterinary Medicine. Benha University.

40. Younis,G.A.;Elkenany,R.M.;Fouda,M.A.andMostafa,N.F.20 17:Virulance and extended spectrum-lactamase encoding genes in Escherichia coli recovered from chicken meat intended for hospitalized human consumption, Veterinary World 10(10): 1281-1285. 